\title{
Airborne Hyperspectral Survey of Afghanistan 2007: Flight Line Planning and HyMap Data Collection
}

By Raymond F. Kokaly, Trude V.V. King, and K. Eric Livo

Open-File Report 2008-1235

USGS Afghanistan Project Product No. 186

U.S. Department of the Interior

U.S. Geological Survey 


\section{U.S. Department of the Interior DIRK KEMPTHORNE, Secretary}

\section{U.S. Geological Survey \\ Mark D. Myers, Director}

U.S. Geological Survey, Reston, Virginia: 2008

For product and ordering information:

World Wide Web: http://www.usgs.gov/pubprod

Telephone: 1-888-ASK-USGS

For more information on the USGS - the Federal source for science about the Earth, its natural and living resources, natural hazards, and the environment:

World Wide Web: http://www.usgs.gov

Telephone: 1-888-ASK-USGS

Suggested citation:

Kokaly, R.F., King, T.V.V., and Livo, K.E., 2008, Airborne Hyperspectral Survey of Afghanistan 2007: Flight Line Planning and HyMap Data Collection: U.S. Geological Survey Open-File Report 2008-1235, $14 \mathrm{p}$.

Any use of trade, product, or firm names is for descriptive purposes only and does not imply endorsement by the U.S. Government.

Although this report is in the public domain, permission must be secured from the individual copyright owners to reproduce any copyrighted material contained within this report. 


\section{Contents}

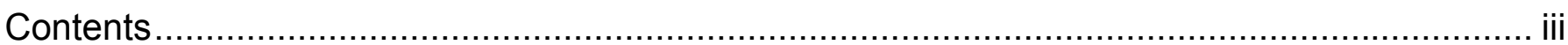

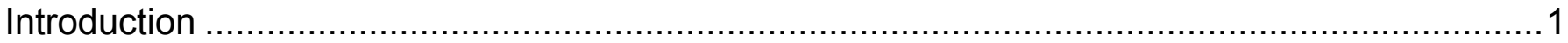

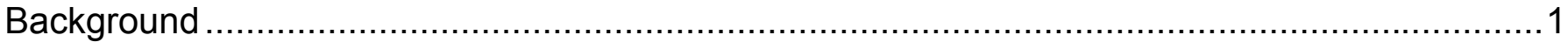

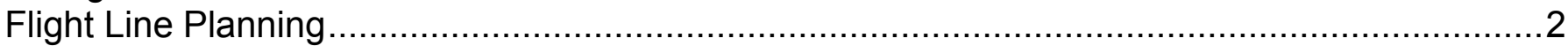

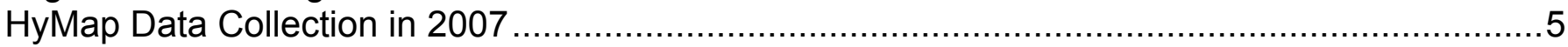

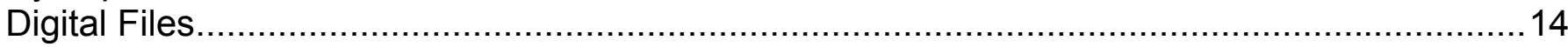

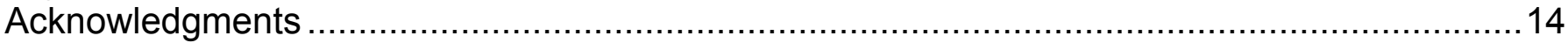

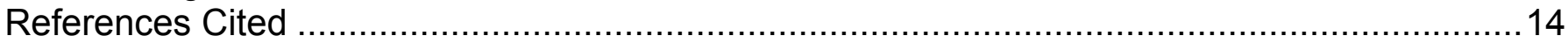

\section{Figures}

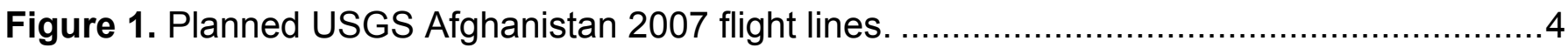

Figure 2. Actually flown USGS Afghanistan 2007 flight lines............................................

\section{Tables}

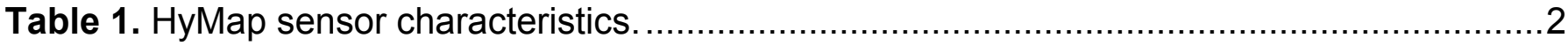

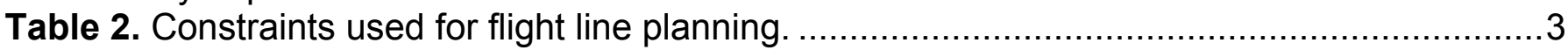

Table 3. Coordinates and characteristics of HyMap lines flown in 2007 ................................

\section{Conversion Factors}

\section{SI to Inch/Pound}

\begin{tabular}{lll}
\hline \multicolumn{1}{c}{ Multiply } & \multicolumn{1}{c}{ By } & \multicolumn{1}{c}{ To obtain } \\
\hline meter $(\mathrm{m})$ & 3.281 & foot $(\mathrm{ft})$ \\
kilometer $(\mathrm{km})$ & 0.6214 & mile $(\mathrm{mi})$ \\
kilometer $(\mathrm{km})$ & 0.5400 & mile, nautical $(\mathrm{nmi})$ \\
square kilometer $\left(\mathrm{km}^{2}\right)$ & 0.3861 & square mile $\left(\mathrm{mi}^{2}\right)$ \\
kilometer per hour $(\mathrm{km} / \mathrm{h})$ & 0.5400 & knots $(\mathrm{kts})$ \\
kilometer per hour $(\mathrm{km} / \mathrm{h})$ & 0.6214 & mile per hour $(\mathrm{mi} / \mathrm{h})$ \\
\hline
\end{tabular}

Vertical coordinate information is referenced to the "North American Vertical Datum of 1988 (NAVD 88)". Horizontal coordinate information is referenced to the "WGS Datum of 1984 (WGS 84)".

Altitude, as used in this report, refers to distance above the vertical datum. 



\title{
Airborne Hyperspectral Survey of Afghanistan 2007: Flight Line Planning and HyMap Data Collection
}

\author{
By Raymond F. Kokaly, ${ }^{1}$ Trude V.V. King, and K. Eric Livo
}

\section{Introduction}

Hyperspectral remote sensing data were acquired over Afghanistan with the HyMap imaging spectrometer (Cocks and others, 1998) operating on the WB-57 high altitude NASA research aircraft (http://jsc-aircraft-ops.jsc.nasa.gov/wb57/index.html). These data were acquired during the interval of August 22, 2007 to October 2, 2007, as part of the United States Geological Survey (USGS) project "Oil and Gas Resources Assessment of the Katawaz and Helmand Basins". A total of 218 flight lines of hyperspectral remote sensing data were collected over the country. This report describes the planning of the airborne survey and the flight lines that were flown. Included with this report are digital files of the nadir tracks of the flight lines, including a map of the labeled flight lines and corresponding vector shape files for geographic information systems (GIS).

\section{Background}

The USGS received funds in 2005 from the government of Afghanistan to support the acquisition of new airborne geophysical (gravity and magnetics) and hyperspectral remote sensing datasets. These datasets were judged to be critical to assessment activities supported by the United States Agency for International Development (USAID). These assessments include coal, water, minerals, and earthquake hazards, as well as southern Afghanistan oil and gas basins in Katawaz and Helmand provinces. The geophysical and remote sensing data will be used to characterize the surface and subsurface rock composition, properties, and structure. They are baseline data needed for resource and hazard assessments and will support and expedite the decision making processes necessary for revitalization of the economic sector of Afghanistan. The airborne geophysical survey was conducted in the summer of 2006. Basic processing of the gravity and magnetic data has been completed (Ashan and others 2007; 2008).

Imaging spectrometers, which provide hyperspectral remote sensing data, measure the reflectance of light from the Earth's surface (Clark and others, 2003). Reflectance spectra can be interpreted to identify specific chemical transitions and molecular bonds and, thus, provide compositional information about specific materials and minerals occurring at the surface where physical- and chemical-weathering processes are active. Using well-characterized laboratory spectral databases as reference "standards," the USGS has conducted numerous remote sensing studies to determine the mineral composition of rocks and soils and map the distribution of minerals and vegetation on the Earth's surface (for example, Clark and others, 2003; Kokaly and others, 2003).

\footnotetext{
${ }^{1}$ Raymond F. Kokaly, USGS, MS 973 Box 25046, Denver Fed Center, Denver CO 80225, USA. raymond@usgs.gov
} 
Hyperspectral remote sensing data collected in Afghanistan will be analyzed to produce thematic maps showing the distribution of selected minerals and vegetation, which will help define areas potentially hosting mineral deposits and will have applications in hazard, hydrologic, and infrastructure assessments. The HyMap imaging spectrometer (Cocks and others, 1998) was flown in Afghanistan from August 22 to October 2, 2007. HyMap has 512 cross-track pixels and covers the wavelength range 0.43 to 2.48 microns in 128 channels. Table 1 shows the nominal spectral characteristics of the four detectors in this sensor.

Table 1. HyMap sensor characteristics

\begin{tabular}{ccccc}
\hline Detector & $\begin{array}{c}\text { Wavelength } \\
\text { Range }(\mathbf{n m})\end{array}$ & $\begin{array}{c}\text { Number of } \\
\text { Channels }\end{array}$ & $\begin{array}{c}\text { Average Sampling } \\
\text { Interval (nm) }\end{array}$ & $\begin{array}{c}\text { Spectral Bandpass (nm) } \\
\text { average (min to max) }\end{array}$ \\
\hline VNIR $^{1}$ & $430-891$ & 32 & 15 & 16 (13 to 20) \\
NIR $^{2}$ & $881-1344$ & 32 & 15 & 16 (14 to 17) \\
SWIR1 $^{3}$ & $1401-1810$ & 32 & 13 & 14 (13 to 16) \\
SWIR2 $^{4}$ & $1948-2480$ & 32 & 17 & 20 (19 to 22) \\
\hline
\end{tabular}

${ }^{1}$ Visible and Near-InfraRed $\quad{ }^{2}$ Near-InfraRed $\quad{ }^{3}$ ShortWave InfraRed detector $1 \quad{ }^{4}$ ShortWave InfraRed detector 2

\section{Flight Line Planning}

Prior to data collection, start and stop coordinates (in latitude and longitude) for each flight line were planned using the software "Survey Planning for Airborne Imaging Spectrometers" (SPAIS, pronounced "space"), a set of custom USGS programs written for the ENVI/IDL software system (ITT, 2007). As shown in Figure 1, flight lines were planned in north-south orientation. Characteristics of the HyMap sensor and the WB-57 aircraft, along with aircraft basing and political-boundary considerations, placed constraints on the design of the flight lines and the conduct of the airborne survey (table 2). With respect to the HyMap sensor, the principal constraints on flight line configuration came from the field of view of the sensor, which controls the width of the data swath, and the hold times of the liquid nitrogen dewars, which limit the hours of operation per flight. Aircraft characteristics also placed constraints on flight line planning, principally from the operational altitude, nominal ground speed, and maximum flight duration.

Additional constraints were placed on the planning of lines as follows. First, the inertial measurement unit, part of the HyMap system, can drift over time for straight and level flight lines, which restricts the flight line durations to a maximum of approximately 20 minutes. Near political borders, buffer zones were established to allow ample room for the WB-57 aircraft to make turns. A buffer zone of $46.3 \mathrm{~km}(25 \mathrm{nmi})$ was used for all borders except the border with Iran, for which a $64.8 \mathrm{~km}$ (35 nmi) buffer was used. The buffered area to be covered by HyMap flight lines, shown by the thin yellow outline in Figure 1, was $438,766 \mathrm{~km}^{2}$.

Flight lines were laid out beginning in the west and moving to the east. The area covered by the sensor as it flies along the nadir track of the flight line is called the swath. The width of the swath varies as a function of surface elevation. The swath is narrower at higher elevations and the distances to the edges of the swath on either side of the nadir track are affected by differences in topography on either side. For the hyperspectral survey in Afghanistan, adjacent lines were planned with a minimum overlap of 40 percent of the "half-swath width" in order to account for these effects. Starting from the first flight line on the western side of the country, the overlap distance used by the SPAIS program to place each subsequent flight line came from the highest elevation at the eastern edge of the swath, which is the narrowest part of the eastern half of the 
swath. For the 512 pixel swath of HyMap, this resulted in approximately 102 pixels of overlap at the highest elevation portions between adjacent flight lines. Determining the spacing in this manner allowed the lines to be spaced closer over high elevation areas of the country where the swaths are narrow and "spaced" wider at low elevations where the swaths are wider. In addition, using the percentage of the half-swath width that lies to the east guaranteed a minimum number of overlapping pixels, while keeping the spacing independent of the elevation effects on the width of the western half of the swath.

Table 2. Constraints used for flight line planning

\begin{tabular}{|c|c|c|c|}
\hline $\begin{array}{l}\text { Source of } \\
\text { Constraint }\end{array}$ & $\begin{array}{l}\text { Constraint } \\
\text { Parameter }\end{array}$ & Constraint Value & Impact of Constrain \\
\hline \multirow[t]{4}{*}{ HyMap Sensor } & Field of View & $61.4^{\circ}$ & $\begin{array}{l}\text { Determines the swath width of } 16.3 \mathrm{~km} \text { using } \\
\text { average country elevation }(1,458 \mathrm{~m}) \text { and nominal } \\
\text { operating altitude }\end{array}$ \\
\hline & $\begin{array}{l}\text { Dewar Hold } \\
\text { Time (from } \\
\text { takeoff) }\end{array}$ & 5 hours & $\begin{array}{l}\text { Limits the number of flight lines that can be flown } \\
\text { per sortie }\end{array}$ \\
\hline & IFOV $^{1}$ & $2.5 \mathrm{mrad}$ along track & $\begin{array}{l}\text { Defines the pixel size in along track direction, which } \\
\text { can limit the ground speed, for a given scan rate, } \\
\text { in order to avoid undersampling in the along track } \\
\text { direction }\end{array}$ \\
\hline & Scan Rate & $8 \mathrm{~Hz}$ & $\begin{array}{l}\text { Determines the nominal along track pixel spacing of } \\
22.5 \mathrm{~m} \text { using the nominal ground speed }\end{array}$ \\
\hline $\begin{array}{c}\text { HyMap } \\
\text { GPS/inertial } \\
\text { measurement } \\
\text { unit }\end{array}$ & $\begin{array}{l}\text { Max. Line } \\
\text { Duration }\end{array}$ & $\sim 20$ minutes & $\begin{array}{l}\text { Limits lines to } \sim 220 \mathrm{~km} \text { length using the nominal } \\
\text { ground speed }\end{array}$ \\
\hline \multirow[t]{3}{*}{ WB-57 Aircraft } & $\begin{array}{l}\text { Nominal } \\
\text { Operating } \\
\text { Altitude }\end{array}$ & $15.24 \mathrm{~km}(50,000 \mathrm{ft})$ & $\begin{array}{l}\text { Determines the swath width of } 16.3 \mathrm{~km} \text { using } \\
\text { average country elevation of } 1,458 \mathrm{~m} \text { and sensor } \\
\text { field of view }\end{array}$ \\
\hline & $\begin{array}{l}\text { Nominal Ground } \\
\text { Speed }\end{array}$ & 648.2 km/h (350 kts) & $\begin{array}{l}\text { Determines the nominal along track spacing of } 22.5 \\
\mathrm{~m} \text { using the given scan rate }\end{array}$ \\
\hline & $\begin{array}{l}\text { Max. Flight } \\
\text { Duration }\end{array}$ & 5.6 hours & $\begin{array}{l}\text { If less than the dewar hold time plus the ferry-out } \\
\text { time, it limits the number of flight lines that can } \\
\text { be collected }\end{array}$ \\
\hline $\begin{array}{l}\text { Flight line } \\
\text { overlap }\end{array}$ & Overlap & Minimum 40 percent & $\begin{array}{l}\text { Applied to the narrowest part of the swath to the east } \\
\text { of the flight line. Determines the flight line } \\
\text { spacing. }\end{array}$ \\
\hline $\begin{array}{l}\text { Airfield } \\
\text { Location }\end{array}$ & $\begin{array}{l}\text { Latitude/ } \\
\text { Longitude }\end{array}$ & $\begin{array}{l}31.50^{\circ} \mathrm{N}, 65.83^{\circ} \mathrm{E} \\
\text { Kandahar Airfield, } \\
\text { Afghanistan }\end{array}$ & $\begin{array}{l}\text { Coordinates of the airfield affect the number of lines } \\
\text { that can be collected in each sortie, for example if } \\
\text { located far from the collection area, the data } \\
\text { collection time is reduced by the time it takes to } \\
\text { ferry-in to the starting point of the data collection }\end{array}$ \\
\hline $\begin{array}{c}\text { Political } \\
\text { Considerations }\end{array}$ & Border Buffer & $\begin{array}{l}64.8 \mathrm{~km}(35 \mathrm{nmi}) \text { for } \\
\text { Iranian border, } 46.3 \mathrm{~km} \\
(25 \mathrm{nmi}) \text { elsewhere }\end{array}$ & $\begin{array}{l}\text { Reduces the area covered and restricts flight lines to } \\
\text { adhere to the buffer zone }\end{array}$ \\
\hline
\end{tabular}

${ }^{1}$ Instantaneous Field Of View 
The combination of sensor scan rate and aircraft ground speed defines the along track spacing. For the hyperspectral survey of Afghanistan, HyMap was set to a scan rate of $8 \mathrm{~Hz}$ and the WB-57 had an estimated ground speed of $648.2 \mathrm{~km} / \mathrm{h}$ (350 kts). The combination of these values results in a $22.5 \mathrm{~m}$ along track pixel spacing at the average elevation of $1,458 \mathrm{~m}(4,783 \mathrm{ft})$ in Afghanistan. To avoid undersampling in the along-track direction the pixel size needs to exceed this value. For the HyMap/WB-57 combination, at the nominal operating altitude, the along-track pixel size is $34.5 \mathrm{~m}$ for this same average elevation. At the lowest elevation of $279 \mathrm{~m}(915 \mathrm{ft})$, the along-track pixel size is $37.4 \mathrm{~m}$. At the highest elevation of 5,642 $\mathrm{m}(18,150 \mathrm{ft})$, the along-track pixel size is $24.0 \mathrm{~m}$. Thus, according to our survey plan, undersampling in the along-track direction would be avoided and most of Afghanistan would be covered with significant scan line overlap.

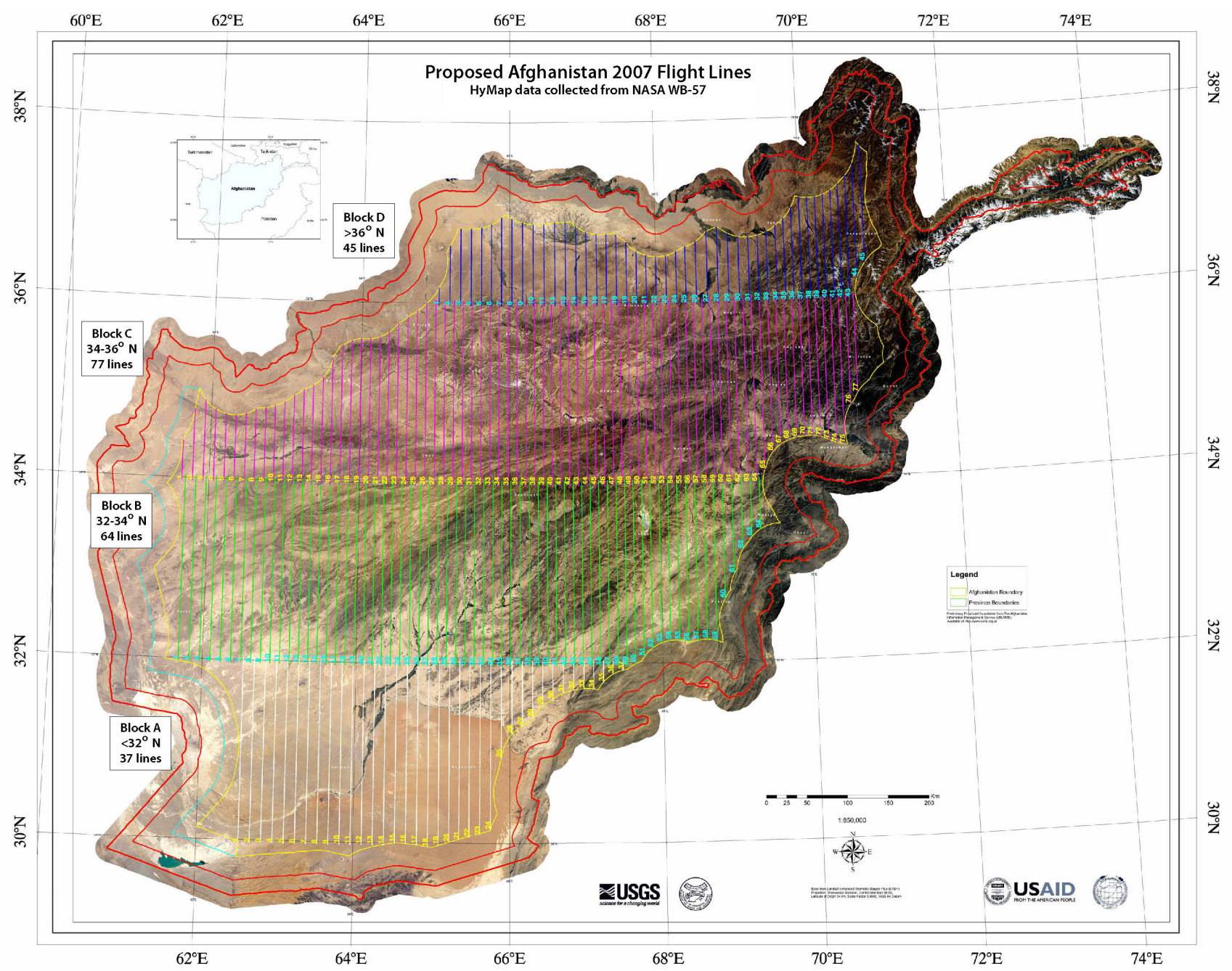

Figure 1. Planned USGS Afghanistan 2007 flight lines. Projection is Transverse Mercator, datum WGS84. Thick red line is the Afghanistan border. Yellow line is the border zone buffer line $(25 \mathrm{nmi}$ on all borders except for the Iranian border where the buffer is $35 \mathrm{nmi}$ ).

Based in part on the above constraints, the country was divided into four "blocks" as defined by latitude (fig. 1). The southern-most block (A) covered the portion of the country below 32 degrees north $(\mathrm{N})$ latitude. Block (B) covered 32 to 34 degrees $\mathrm{N}$ latitude. Block C covered 34 to 36 degrees $\mathrm{N}$ latitude. The northern-most block $\mathrm{D}$ covered the portion of the country above 36 
degrees N latitude. For each block, the SPAIS program was run using an 85 meter digital elevation model (DEM), the buffer zone constraints, the HyMap sensor characteristics, and the WB-57 aircraft characteristics. To allow for overlap across blocks, an extra $3 \mathrm{~km}$ was added to the ends of each flight line, resulting in maximum lengths of $228 \mathrm{~km}$ (21 minutes flight time) for lines that would span a full 2 degrees of latitude. In Figure 1, the resulting 223 flight lines are depicted on a background Landsat image mosaic. These are the "standard data lines" for full country coverage of Afghanistan within our boundary buffer. The average planned flight line spacing was $11.5 \mathrm{~km}$ ( minimum $=9.2 \mathrm{~km}$, maximum $=13.8 \mathrm{~km}$ ). The average swath width of the planned flight lines was $15.8 \mathrm{~km}($ minimum $=11.7 \mathrm{~km}$, maximum $=17.7 \mathrm{~km})$. Additional flight lines, not depicted in Figure 1, were planned to pass over locations where field samples were collected and where measurements of field reflectance calibration sites were planned. These lines were designated "cross-calibration lines".

Output of the SPAIS flight line planning software includes an estimate of the number of flights needed to acquire these flight lines based on the coordinates of the airfield, the start/stop coordinates and lengths of the flight lines, the turn times (estimated at 7 minutes for the WB-57), and the duration of each flight day (constrained by dewar hold time and maximum aircraftoperating duration). For the 223 flight lines, the total number of flights (sorties) was estimated to be approximately 19 . Factoring in 50 percent down time due to aircraft maintenance, sensor maintenance, and weather, the collection time to complete the airborne hyperspectral survey was estimated to be 29 days.

\section{HyMap Data Collection in 2007}

Over the course of 43 days and 28 flights, from August 22 to October 2, 2007, a total of 218 flight lines of HyMap data were collected from the WB-57 aircraft. These flight lines include 207 standard data lines and 11 cross-calibration lines (see Figure 2), totaling 39,546 km in line length. The total area of Afghanistan imaged was approximately $438,012 \mathrm{~km}^{2}$.

The majority of flight lines were collected according to the plan in Figure 1, with the exception of block A and the western-most lines in blocks B-D. For the last six flights of the data collection, the remaining lines were re-planned with less overlap. The observed stability of the WB-57 aircraft, with respect to roll, pitch and yaw, facilitated our reduction in overlap. Original flight lines D004-026 were re-planned with 16 percent overlap, resulting in 3 fewer lines to cover with the re-programmed lines D004-023. Flight line D001 was not flown. Similarly, C001-023 and B001-007 were re-planned with 14 percent overlap, reducing the number of flight lines needed to cover blocks $\mathrm{C}$ and $\mathrm{B}$ by 4 and 2, respectively. Originally planned lines A001 to 025 of block A were re-planned to lines A001-021 with 12 percent overlap. The eastern part of block A, originally covered by north-south lines A026-037, was re-planned to flight lines A022-028 and oriented 49.3 degrees east of north. Three lines, A029-031, were added to cover the Chagai hills in southern Afghanistan. Very poor visibility caused by dust storms on the last sortie of the deployment resulted in lines A002-006 and A015-019 being shortened so that they do not extend to 30 degrees $\mathrm{N}$ latitude as planned. Eleven cross-calibration lines were flown. Part of cross-calibration line K001 fills the gap between standard data lines A023 and A024. 


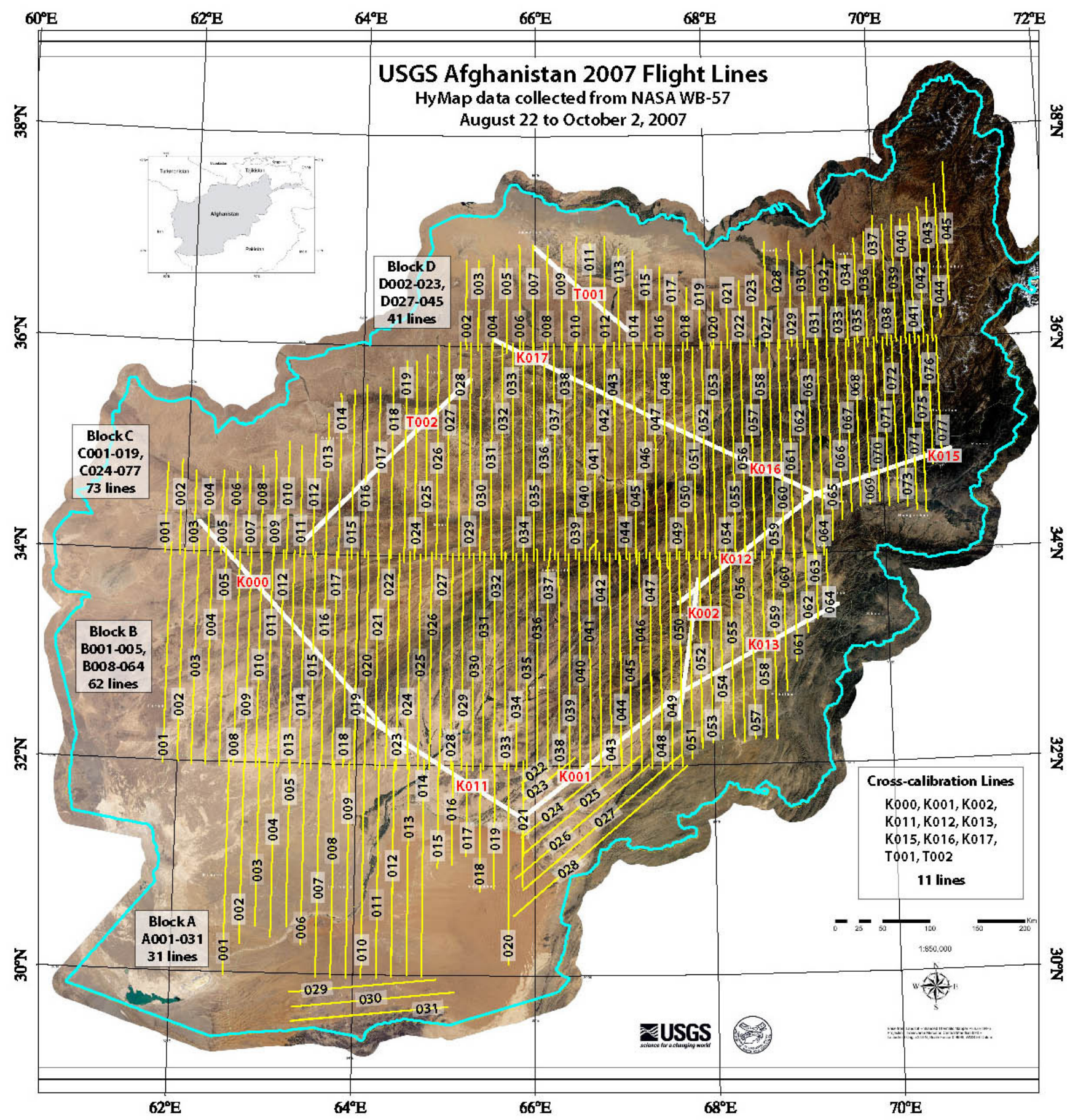

Figure 2. Actually flown USGS Afghanistan 2007 flight lines. Projection is Transverse Mercator, datum WGS-84. Cyan line is the Afghanistan border. 
Compared to the flight line plan, the factors that were found to increase the number of sorties and days needed to actually complete the survey included:

1) five down days due to sensor problems caused by operating at high altitude

2) eight down days waiting for aircraft parts due in part to the difficulty of getting deliveries to the airfield

3) vacuum loss in HyMap's SWIR1 and SWIR2 dewars caused short collection times on two flights and led to two down days

4) less than optimal collection for the first seven fights, due to sensor problems

5) shorter than expected data collection times, measured from takeoff, that averaged 4.4 hours

On two occasions, right after detector dewars were vacuum pumped and when flight lines were located close to the Kandahar air field, data collection time reached the estimate of five hours used in the survey planning. During flights in Afghanistan, the actual altitudes and ground speeds were higher than originally planned. The mean altitude was $16.06 \mathrm{~km}(52,690 \mathrm{ft})$, minimum $=15.79 \mathrm{~km}$ $(51,804 \mathrm{ft})$, maximum $=16.34 \mathrm{~km}(53,609 \mathrm{ft})$. The mean ground speed was $734.3 \mathrm{~km} / \mathrm{h}(396.5 \mathrm{kts})$, minimum $=656.7 \mathrm{~km} / \mathrm{h}(354.6 \mathrm{kts})$, maximum $=837.0 \mathrm{~km} / \mathrm{h}(451.9 \mathrm{kts})$.

The increase in average ground speed was 13.8 percent above the planned value; however, the average altitude increased only 5.4 percent over the planned value. As a result the along-track pixel spacing (which scales with ground speed) increased more than the along-track pixel size (which scales with altitude). The consequence of the higher increase in ground speed was some undersampling in the along-track direction. Based on a preliminary analysis of the ground speeds, altitudes, and surface elevations, undersampling is a possibility in the data collected over higher elevations in the country, above 3,500 meters $(11,483 \mathrm{ft})$, which is approximately 5 percent of the area covered by HyMap. Above this elevation limit, the along-track pixel spacing is likely to exceed the along track pixel size by one to two meters. The worst undersampling appears to be for the eastern-most lines in blocks $\mathrm{C}$ and $\mathrm{D}$, caused by the very high terrain combined with strong tail winds from the north that increased ground speed for south-bound flight lines. The lines with high ground speeds include: C064, C066, C068, and C070, covered on sortie 8; C072, C074, and C076, covered on sortie 13; and D042 and D044 covered on sortie 14. The interspersed odd-numbered lines had lower ground speeds and did not suffer from undersampling. Considering the shorter than expected data-collection times, the ability to collect more data lines on each flight with higher ground speeds was judged to outweigh the disadvantage of potential along-track undersampling at high elevations.

The actual start and stop coordinates of all flown lines are given in Table 3, along with flight date, and time of collection.

Table 3. Coordinates and characteristics of HyMap lines flown in 2007

\begin{tabular}{cccccccc}
\hline $\begin{array}{c}\text { Flight } \\
\text { Line } \\
\text { Name }\end{array}$ & Sortie \# & $\begin{array}{c}\text { Flight } \\
\text { Date }\end{array}$ & $\begin{array}{c}\text { UTC } \\
\text { Time of } \\
\text { Collection } \\
\text { hh:mm:ss }\end{array}$ & $\begin{array}{c}\text { Start } \\
\text { Latitude }\end{array}$ & $\begin{array}{c}\text { Start } \\
\text { Longitude }\end{array}$ & $\begin{array}{c}\text { Stop } \\
\text { Latitude }\end{array}$ & $\begin{array}{c}\text { Stop } \\
\text { Longitude }\end{array}$ \\
\hline A001 & 28 & $10 / 2 / 2007$ & $08: 05: 22$ & 29.972124 & 62.580273 & 32.029545 & 62.579906 \\
A002 & 28 & $10 / 2 / 2007$ & $08: 27: 05$ & 32.027592 & 62.747765 & 30.275385 & 62.749393 \\
A003 & 28 & $10 / 2 / 2007$ & $08: 48: 19$ & 30.443548 & 62.918621 & 32.032040 & 62.918777 \\
A004 & 28 & $10 / 2 / 2007$ & $09: 07: 44$ & 32.027386 & 63.088913 & 30.345081 & 63.088116 \\
A005 & 28 & $10 / 2 / 2007$ & $09: 26: 46$ & 30.447092 & 63.261185 & 32.029652 & 63.257076 \\
\hline
\end{tabular}




\begin{tabular}{|c|c|c|c|c|c|c|c|}
\hline A006 & 28 & $10 / 2 / 2007$ & $09: 46: 32$ & 32.028580 & 63.424465 & 30.280624 & 63.424503 \\
\hline A007 & 26 & $9 / 30 / 2007$ & $08: 10: 50$ & 32.027447 & 63.592514 & 29.974766 & 63.591255 \\
\hline A008 & 26 & $9 / 30 / 2007$ & $08: 34: 21$ & 29.971659 & 63.754513 & 32.028042 & 63.757092 \\
\hline A009 & 26 & $9 / 30 / 2007$ & $08: 58: 57$ & 32.027325 & 63.923180 & 29.971437 & 63.922886 \\
\hline A010 & 26 & $9 / 30 / 2007$ & $09: 23: 23$ & 29.974432 & 64.087555 & 32.029762 & 64.088921 \\
\hline A011 & 26 & $9 / 30 / 2007$ & $09: 47: 59$ & 32.028687 & 64.256180 & 29.972521 & 64.254662 \\
\hline A012 & 26 & $9 / 30 / 2007$ & $10: 12: 25$ & 29.988613 & 64.419830 & 32.029861 & 64.420807 \\
\hline A013 & 26 & $9 / 30 / 2007$ & $10: 37: 06$ & 32.026783 & 64.587189 & 30.001612 & 64.586815 \\
\hline $\mathrm{A} 014$ & 26 & $9 / 30 / 2007$ & 11:00:56 & 29.988289 & 64.750656 & 32.055565 & 64.751846 \\
\hline A015 & 28 & $10 / 2 / 2007$ & $10: 21: 54$ & 31.027197 & 64.916740 & 32.031624 & 64.916771 \\
\hline A016 & 28 & $10 / 2 / 2007$ & $10: 35: 15$ & 32.027229 & 65.077225 & 31.061424 & 65.074799 \\
\hline A017 & 28 & $10 / 2 / 2007$ & $10: 49: 11$ & 31.141773 & 65.233597 & 32.027760 & 65.233429 \\
\hline A018 & 28 & $10 / 2 / 2007$ & 11:04:55 & 32.024864 & 65.384918 & 30.803396 & 65.384506 \\
\hline A019 & 28 & $10 / 2 / 2007$ & $11: 21: 07$ & 30.832409 & 65.542862 & 32.033409 & 65.540848 \\
\hline A020 & 27 & $10 / 1 / 2007$ & $10: 56: 41$ & 30.108656 & 65.708885 & 32.027615 & 65.701218 \\
\hline $\mathrm{A} 021$ & 27 & $10 / 1 / 2007$ & $10: 32: 55$ & 32.045490 & 65.863678 & 30.851093 & 65.860115 \\
\hline A022 & 27 & $10 / 1 / 2007$ & $10: 21: 23$ & 31.842796 & 65.848572 & 32.001701 & 66.098869 \\
\hline A023 & 27 & $10 / 1 / 2007$ & $10: 14: 24$ & 32.078110 & 66.441238 & 31.678572 & 65.868835 \\
\hline $\mathrm{A} 024$ & 27 & $10 / 1 / 2007$ & $10: 02: 07$ & 31.320242 & 65.841537 & 32.000179 & 66.807167 \\
\hline A025 & 27 & $10 / 1 / 2007$ & $09: 47: 52$ & 32.093502 & 67.168991 & 31.165438 & 65.868401 \\
\hline A026 & 27 & $10 / 1 / 2007$ & 09:31:01 & 30.930769 & 65.778038 & 32.005318 & 67.266472 \\
\hline $\mathrm{A} 027$ & 27 & $10 / 1 / 2007$ & 09:10:48 & 32.097301 & 67.622650 & 30.823099 & 65.867844 \\
\hline A028 & 27 & $10 / 1 / 2007$ & 08:48:42 & 30.573492 & 65.763512 & 31.995325 & 67.694946 \\
\hline A029 & 27 & 10/1/2007 & $08: 25: 43$ & 29.824646 & 63.309620 & 29.962446 & 64.906059 \\
\hline A030 & 27 & $10 / 1 / 2007$ & 08:08:06 & 29.842499 & 65.107857 & 29.684048 & 63.346123 \\
\hline A031 & 27 & $10 / 1 / 2007$ & 07:51:35 & 29.548759 & 63.333328 & 29.703384 & 65.040039 \\
\hline B001 & 24 & $9 / 28 / 2007$ & 09:38:07 & 34.073719 & 61.846031 & 31.978779 & 61.841583 \\
\hline B002 & 24 & $9 / 28 / 2007$ & 10:01:03 & 31.990074 & 62.011196 & 34.020382 & 62.000778 \\
\hline B003 & 26 & $9 / 30 / 2007$ & $06: 52: 34$ & 34.020714 & 62.157555 & 31.970463 & 62.157871 \\
\hline B004 & 26 & $9 / 30 / 2007$ & 07:16:28 & 31.971947 & 62.312950 & 34.031094 & 62.314983 \\
\hline B005 & 26 & $9 / 30 / 2007$ & 07:40:06 & 34.028496 & 62.471642 & 31.964602 & 62.470657 \\
\hline B008 & 19 & $9 / 21 / 2007$ & $11: 55: 23$ & 31.965862 & 62.629883 & 34.032043 & 62.629990 \\
\hline B009 & 19 & $9 / 21 / 2007$ & $11: 31: 41$ & 34.035809 & 62.756809 & 31.965347 & 62.756985 \\
\hline B010 & 19 & $9 / 21 / 2007$ & 11:08:16 & 31.960194 & 62.879032 & 34.032303 & 62.878994 \\
\hline B011 & 19 & $9 / 21 / 2007$ & $10: 44: 43$ & 34.037342 & 63.004124 & 31.965561 & 63.003975 \\
\hline B012 & 19 & $9 / 21 / 2007$ & $10: 20: 44$ & 31.967615 & 63.126049 & 34.033459 & 63.127052 \\
\hline
\end{tabular}




\begin{tabular}{|c|c|c|c|c|c|c|c|}
\hline B013 & 19 & $9 / 21 / 2007$ & $09: 56: 45$ & 34.031593 & 63.249424 & 31.965904 & 63.248993 \\
\hline B014 & 19 & $9 / 21 / 2007$ & 09:33:03 & 31.963531 & 63.369492 & 34.032837 & 63.370010 \\
\hline B015 & 18 & $9 / 17 / 2007$ & $09: 10: 44$ & 31.953680 & 63.493484 & 34.022552 & 63.489296 \\
\hline B016 & 18 & 9/17/2007 & $08: 47: 13$ & 34.049267 & 63.610653 & 31.977661 & 63.609764 \\
\hline B017 & 18 & $9 / 17 / 2007$ & $08: 22: 55$ & 31.961380 & 63.735371 & 34.024570 & 63.732059 \\
\hline B018 & 18 & $9 / 17 / 2007$ & $07: 59: 29$ & 34.036983 & 63.853638 & 31.979948 & 63.854923 \\
\hline B019 & 18 & $9 / 17 / 2007$ & $07: 35: 22$ & 31.960926 & 63.977417 & 34.022816 & 63.975140 \\
\hline B020 & 18 & $9 / 17 / 2007$ & $07: 11: 57$ & 34.037266 & 64.092964 & 31.978275 & 64.092911 \\
\hline B021 & 18 & $9 / 17 / 2007$ & $06: 47: 40$ & 31.962265 & 64.211426 & 34.021843 & 64.209358 \\
\hline B022 & 18 & 9/17/2007 & $06: 23: 50$ & 34.054237 & 64.329170 & 31.980976 & 64.328621 \\
\hline B023 & 18 & $9 / 17 / 2007$ & $05: 59: 26$ & 31.961405 & 64.446785 & 34.021812 & 64.447472 \\
\hline B024 & 18 & $9 / 17 / 2007$ & $05: 31: 54$ & 34.042450 & 64.568504 & 31.968777 & 64.567413 \\
\hline B025 & 17 & $9 / 16 / 2007$ & $10: 28: 45$ & 34.018566 & 64.688416 & 31.967522 & 64.688866 \\
\hline B026 & 17 & $9 / 16 / 2007$ & 10:04:05 & 31.977324 & 64.816795 & 34.032730 & 64.816017 \\
\hline B027 & 17 & $9 / 16 / 2007$ & $09: 40: 27$ & 34.023693 & 64.930069 & 31.968115 & 64.931831 \\
\hline B028 & 17 & $9 / 16 / 2007$ & $09: 15: 44$ & 31.973734 & 65.055099 & 34.030422 & 65.052902 \\
\hline B029 & 17 & $9 / 16 / 2007$ & $08: 51: 48$ & 34.031853 & 65.173698 & 31.969517 & 65.175034 \\
\hline B030 & 17 & $9 / 16 / 2007$ & $08: 27: 26$ & 31.974377 & 65.298241 & 34.033195 & 65.298012 \\
\hline B031 & 17 & $9 / 16 / 2007$ & 08:03:11 & 34.045078 & 65.416481 & 31.970285 & 65.416939 \\
\hline B032 & 17 & $9 / 16 / 2007$ & 07:38:11 & 31.957541 & 65.535500 & 34.030056 & 65.535950 \\
\hline B033 & 17 & $9 / 16 / 2007$ & $07: 13: 44$ & 34.045948 & 65.656242 & 31.972569 & 65.652023 \\
\hline B034 & 16 & $9 / 15 / 2007$ & 06:06:59 & 31.962019 & 65.781265 & 34.032764 & 65.781075 \\
\hline B035 & 16 & $9 / 15 / 2007$ & 05:43:05 & 34.036228 & 65.902313 & 31.968710 & 65.898941 \\
\hline B036 & 15 & $9 / 14 / 2007$ & $10: 41: 27$ & 34.073910 & 66.014679 & 31.955479 & 66.017014 \\
\hline B037 & 15 & $9 / 14 / 2007$ & $10: 18: 37$ & 31.957645 & 66.137566 & 34.085136 & 66.167717 \\
\hline B038 & 15 & $9 / 14 / 2007$ & $09: 54: 26$ & 34.039577 & 66.262962 & 31.974222 & 66.263031 \\
\hline B039 & 15 & $9 / 14 / 2007$ & 09:29:41 & 31.960991 & 66.381187 & 34.029041 & 66.380928 \\
\hline B040 & 15 & $9 / 14 / 2007$ & 09:05:37 & 34.043987 & 66.498199 & 31.968033 & 66.499031 \\
\hline B041 & 15 & $9 / 14 / 2007$ & 08:41:51 & 31.954849 & 66.615425 & 34.159031 & 66.710320 \\
\hline B042 & 15 & $9 / 14 / 2007$ & $08: 16: 52$ & 34.040115 & 66.730057 & 31.970829 & 66.730003 \\
\hline B043 & 15 & $9 / 14 / 2007$ & $07: 52: 15$ & 31.960949 & 66.845978 & 34.026474 & 66.846092 \\
\hline B044 & 15 & $9 / 14 / 2007$ & $07: 27: 47$ & 34.041088 & 66.959785 & 31.977633 & 66.959961 \\
\hline B045 & 15 & $9 / 14 / 2007$ & 07:03:23 & 31.958145 & 67.070793 & 34.027279 & 67.070961 \\
\hline B046 & 15 & $9 / 14 / 2007$ & $06: 39: 34$ & 34.037300 & 67.187912 & 31.969109 & 67.184982 \\
\hline B047 & 12 & $9 / 10 / 2007$ & $08: 07: 27$ & 34.034359 & 67.302505 & 31.978226 & 67.301079 \\
\hline B048 & 7 & $9 / 5 / 2007$ & 08:20:32 & 31.960108 & 67.417580 & 34.034946 & 67.416992 \\
\hline
\end{tabular}




\begin{tabular}{|c|c|c|c|c|c|c|c|}
\hline B049 & 7 & $9 / 5 / 2007$ & $07: 55: 18$ & 34.034374 & 67.531105 & 31.967699 & 67.530991 \\
\hline B050 & 7 & $9 / 5 / 2007$ & 07:30:16 & 31.990335 & 67.639862 & 34.035908 & 67.639977 \\
\hline B051 & 7 & $9 / 5 / 2007$ & 07:06:18 & 34.034409 & 67.749138 & 32.062412 & 67.756004 \\
\hline B052 & 6 & $9 / 4 / 2007$ & $07: 29: 32$ & 34.035351 & 67.868286 & 32.163132 & 67.867577 \\
\hline B053 & 6 & $9 / 4 / 2007$ & 07:06:48 & 32.216206 & 67.987816 & 34.028709 & 67.986679 \\
\hline B054 & 6 & $9 / 4 / 2007$ & $06: 44: 26$ & 34.036575 & 68.102226 & 32.246082 & 68.101273 \\
\hline B055 & 6 & $9 / 4 / 2007$ & $06: 22: 14$ & 32.267876 & 68.235542 & 34.025433 & 68.223923 \\
\hline B056 & 5 & $9 / 3 / 2007$ & $06: 17: 26$ & 32.215542 & 68.341255 & 34.032124 & 68.341064 \\
\hline B057 & 4 & 8/30/2007 & 09:49:16 & 34.026146 & 68.458267 & 32.240601 & 68.462700 \\
\hline B058 & 4 & $8 / 30 / 2007$ & $09: 27: 08$ & 32.254524 & 68.579338 & 34.027958 & 68.584518 \\
\hline B059 & 4 & 8/30/2007 & 09:06:26 & 34.017170 & 68.698341 & 32.235401 & 68.706764 \\
\hline B060 & 4 & 8/30/2007 & $08: 46: 29$ & 32.697247 & 68.833275 & 34.029049 & 68.828186 \\
\hline B061 & 4 & 8/30/2007 & $08: 29: 59$ & 34.027481 & 68.954880 & 32.969460 & 68.953506 \\
\hline B062 & 4 & $8 / 30 / 2007$ & 08:02:20 & 33.243706 & 69.085678 & 34.026875 & 69.079842 \\
\hline B063 & 4 & 8/30/2007 & 07:51:07 & 34.024643 & 69.197723 & 33.371891 & 69.199028 \\
\hline B064 & 4 & 8/30/2007 & 07:39:12 & 33.453495 & 69.319954 & 34.030514 & 69.320465 \\
\hline C001 & 24 & 9/28/2007 & $09: 18: 45$ & 34.825958 & 61.773487 & 33.979733 & 61.770069 \\
\hline C002 & 24 & 9/28/2007 & 09:08:32 & 33.961853 & 61.940205 & 34.862396 & 61.936771 \\
\hline $\mathrm{C003}$ & 24 & 9/28/2007 & 08:58:20 & 34.763992 & 62.100616 & 33.980316 & 62.099567 \\
\hline C004 & 24 & 9/28/2007 & 08:48:28 & 33.961834 & 62.258984 & 34.704079 & 62.259174 \\
\hline C005 & 24 & $9 / 28 / 2007$ & 08:38:05 & 34.771595 & 62.416279 & 33.978722 & 62.413094 \\
\hline C006 & 24 & 9/28/2007 & $08: 27: 32$ & 33.937008 & 62.568279 & 34.759651 & 62.567554 \\
\hline $\mathrm{C} 007$ & 22 & $9 / 24 / 2007$ & $10: 14: 44$ & 34.819820 & 62.715614 & 33.981037 & 62.720055 \\
\hline C008 & 22 & $9 / 24 / 2007$ & $10: 02: 39$ & 33.948025 & 62.868305 & 34.831459 & 62.867981 \\
\hline C009 & 22 & $9 / 24 / 2007$ & $09: 50: 33$ & 34.969303 & 62.999454 & 33.978828 & 63.015675 \\
\hline $\mathrm{C} 010$ & 22 & 9/24/2007 & $09: 37: 37$ & 33.948086 & 63.153526 & 35.068981 & 63.161205 \\
\hline $\mathrm{C} 011$ & 22 & 9/24/2007 & 09:24:48 & 35.031334 & 63.300545 & 33.978291 & 63.312309 \\
\hline C012 & 22 & $9 / 24 / 2007$ & 09:11:09 & 33.974232 & 63.472168 & 35.137058 & 63.460289 \\
\hline $\mathrm{C} 013$ & 22 & 9/24/2007 & 08:38:11 & 33.963287 & 63.607651 & 35.341824 & 63.606987 \\
\hline C014 & 22 & $9 / 24 / 2007$ & 08:55:34 & 35.533375 & 63.743862 & 33.981762 & 63.752327 \\
\hline $\mathrm{C} 015$ & 22 & $9 / 24 / 2007$ & 08:02:20 & 33.962555 & 63.902443 & 35.569485 & 63.900078 \\
\hline C016 & 22 & $9 / 24 / 2007$ & $07: 43: 46$ & 35.624142 & 64.046875 & 33.981892 & 64.047768 \\
\hline C017 & 22 & $9 / 24 / 2007$ & 07:25:05 & 33.961246 & 64.197830 & 35.596928 & 64.195198 \\
\hline C018 & 22 & $9 / 24 / 2007$ & $07: 05: 26$ & 35.792370 & 64.342758 & 33.981247 & 64.348419 \\
\hline C019 & 22 & $9 / 24 / 2007$ & $06: 45: 33$ & 33.936134 & 64.502312 & 35.856976 & 64.502899 \\
\hline $\mathrm{C} 024$ & 11 & 9/9/2007 & $08: 31: 57$ & 33.963821 & 64.621735 & 35.852337 & 64.618965 \\
\hline
\end{tabular}




\begin{tabular}{|c|c|c|c|c|c|c|c|}
\hline $\mathrm{C} 025$ & 11 & 9/9/2007 & 08:09:56 & 35.915565 & 64.740303 & 33.960503 & 64.744003 \\
\hline $\mathrm{C} 026$ & 11 & 9/9/2007 & $07: 46: 15$ & 33.966904 & 64.870499 & 36.003956 & 64.870003 \\
\hline $\mathrm{C} 027$ & 11 & 9/9/2007 & $07: 22: 02$ & 36.031673 & 64.993401 & 33.962040 & 64.996010 \\
\hline $\mathrm{C} 028$ & 11 & 9/9/2007 & $06: 57: 58$ & 33.962017 & 65.123116 & 36.037430 & 65.120995 \\
\hline C029 & 21 & $9 / 23 / 2007$ & 09:09:54 & 33.988693 & 65.244972 & 36.035343 & 65.245033 \\
\hline $\mathrm{C} 030$ & 21 & $9 / 23 / 2007$ & $08: 46: 55$ & 36.025578 & 65.366844 & 33.968071 & 65.366951 \\
\hline $\mathrm{C} 031$ & 21 & $9 / 23 / 2007$ & $08: 23: 37$ & 33.973499 & 65.491280 & 36.032852 & 65.491013 \\
\hline C032 & 21 & $9 / 23 / 2007$ & 08:00:44 & 36.028469 & 65.614143 & 33.968647 & 65.615028 \\
\hline $\mathrm{C} 033$ & 11 & 9/9/2007 & $06: 32: 24$ & 36.037807 & 65.737656 & 33.962440 & 65.737930 \\
\hline $\mathrm{C} 034$ & 11 & 9/9/2007 & 06:08:25 & 33.961876 & 65.859673 & 36.040932 & 65.858994 \\
\hline $\mathrm{C} 035$ & 11 & 9/9/2007 & $05: 44: 13$ & 36.036213 & 65.980080 & 33.960228 & 65.980026 \\
\hline C036 & 11 & 9/9/2007 & 05:19:56 & 33.963936 & 66.099617 & 36.037277 & 66.099060 \\
\hline $\mathrm{C} 037$ & 12 & $9 / 10 / 2007$ & 07:40:08 & 36.026432 & 66.219009 & 33.977783 & 66.217773 \\
\hline $\mathrm{C} 038$ & 12 & $9 / 10 / 2007$ & $07: 15: 42$ & 33.968300 & 66.338608 & 36.020088 & 66.336929 \\
\hline C039 & 12 & $9 / 10 / 2007$ & $06: 51: 24$ & 36.033009 & 66.456566 & 33.979973 & 66.455017 \\
\hline $\mathrm{C} 040$ & 12 & $9 / 10 / 2007$ & $06: 27: 01$ & 33.966454 & 66.569389 & 36.021202 & 66.567993 \\
\hline C041 & 12 & $9 / 10 / 2007$ & $06: 02: 55$ & 36.024879 & 66.686974 & 33.970566 & 66.685280 \\
\hline $\mathrm{C} 042$ & 12 & $9 / 10 / 2007$ & $05: 38: 43$ & 33.959511 & 66.800491 & 36.021374 & 66.799995 \\
\hline $\mathrm{C} 043$ & 12 & $9 / 10 / 2007$ & $05: 14: 07$ & 36.035259 & 66.916679 & 33.977913 & 66.916389 \\
\hline $\mathrm{C} 044$ & 12 & $9 / 10 / 2007$ & 04:50:02 & 33.967941 & 67.040733 & 36.020798 & 67.036209 \\
\hline C045 & 24 & $9 / 28 / 2007$ & $06: 51: 33$ & 33.922138 & 67.149673 & 36.021034 & 67.149040 \\
\hline $\mathrm{C} 046$ & 10 & 9/8/2007 & 08:58:07 & 36.034557 & 67.268158 & 33.982590 & 67.268028 \\
\hline $\mathrm{C} 047$ & 10 & $9 / 8 / 2007$ & $08: 32: 14$ & 33.971928 & 67.388229 & 36.024956 & 67.385963 \\
\hline C048 & 10 & $9 / 8 / 2007$ & 08:07:03 & 36.032448 & 67.497475 & 33.878624 & 67.516869 \\
\hline C049 & 10 & $9 / 8 / 2007$ & 07:39:58 & 33.966606 & 67.614281 & 36.022640 & 67.611954 \\
\hline $\mathrm{C} 050$ & 10 & $9 / 8 / 2007$ & 07:14:20 & 36.032021 & 67.721291 & 33.975346 & 67.721916 \\
\hline $\mathrm{C} 051$ & 10 & $9 / 8 / 2007$ & $06: 47: 19$ & 33.968616 & 67.835541 & 35.983593 & 67.832886 \\
\hline C052 & 10 & 9/8/2007 & $06: 22: 02$ & 36.031750 & 67.944481 & 33.975319 & 67.943626 \\
\hline $\mathrm{C} 053$ & 10 & $9 / 8 / 2007$ & 05:57:01 & 33.966537 & 68.054497 & 36.024258 & 68.054222 \\
\hline $\mathrm{C} 054$ & 9 & 9/7/2007 & 08:27:49 & 36.032814 & 68.167717 & 33.963730 & 68.169891 \\
\hline C055 & 9 & 9/7/2007 & 08:03:02 & 33.964771 & 68.286201 & 36.038200 & 68.283905 \\
\hline C056 & 9 & 9/7/2007 & $07: 38: 41$ & 36.041737 & 68.393433 & 33.959732 & 68.395004 \\
\hline C057 & 9 & 9/7/2007 & $07: 13: 49$ & 33.967461 & 68.505005 & 36.038670 & 68.504883 \\
\hline C058 & 9 & 9/7/2007 & $06: 49: 32$ & 36.027294 & 68.618454 & 33.964317 & 68.618935 \\
\hline C059 & 9 & 9/7/2007 & $06: 24: 20$ & 33.969894 & 68.728615 & 36.037731 & 68.728973 \\
\hline $\mathrm{C} 060$ & 21 & 9/23/2007 & $06: 19: 51$ & 33.974651 & 68.835670 & 36.032604 & 68.835999 \\
\hline
\end{tabular}




\begin{tabular}{|c|c|c|c|c|c|c|c|}
\hline $\mathrm{C} 061$ & 21 & $9 / 23 / 2007$ & $06: 43: 49$ & 36.024311 & 68.948006 & 33.968010 & 68.948051 \\
\hline C062 & 20 & $9 / 22 / 2007$ & 10:35:04 & 36.060242 & 69.059799 & 33.972347 & 69.061066 \\
\hline C063 & 20 & $9 / 22 / 2007$ & $06: 56: 50$ & 33.948513 & 69.179649 & 36.018684 & 69.180855 \\
\hline C064 & 8 & $9 / 6 / 2007$ & 09:12:15 & 36.034111 & 69.292427 & 33.976345 & 69.290909 \\
\hline C065 & 8 & $9 / 6 / 2007$ & 08:49:15 & 34.116577 & 69.396584 & 36.034142 & 69.403320 \\
\hline C066 & 8 & 9/6/2007 & 08:26:58 & 36.034088 & 69.517479 & 34.312187 & 69.515747 \\
\hline C067 & 8 & 9/6/2007 & 08:05:52 & 34.384205 & 69.627655 & 36.022923 & 69.625130 \\
\hline C068 & 8 & $9 / 6 / 2007$ & $07: 45: 40$ & 36.029507 & 69.734406 & 34.436829 & 69.731773 \\
\hline C069 & 8 & 9/6/2007 & $07: 25: 41$ & 34.452461 & 69.842880 & 36.022030 & 69.841980 \\
\hline C070 & 8 & 9/6/2007 & 07:05:00 & 36.025917 & 69.955307 & 34.473240 & 69.949760 \\
\hline $\mathrm{C} 071$ & 13 & $9 / 11 / 2007$ & $06: 59: 49$ & 34.425434 & 70.057816 & 36.025234 & 70.056938 \\
\hline C072 & 13 & $9 / 11 / 2007$ & $06: 40: 27$ & 36.039825 & 70.161751 & 34.453491 & 70.161896 \\
\hline $\mathrm{C} 073$ & 13 & $9 / 11 / 2007$ & 06:20:31 & 34.410221 & 70.268425 & 36.025585 & 70.267952 \\
\hline C074 & 13 & $9 / 11 / 2007$ & 06:00:24 & 36.042034 & 70.372665 & 34.381947 & 70.373947 \\
\hline $\mathrm{C} 075$ & 13 & $9 / 11 / 2007$ & 05:39:38 & 34.354729 & 70.479584 & 36.026268 & 70.480026 \\
\hline C076 & 13 & $9 / 11 / 2007$ & 05:18:26 & 36.031044 & 70.581924 & 34.803314 & 70.581932 \\
\hline C077 & 13 & $9 / 11 / 2007$ & 05:01:05 & 34.896465 & 70.682137 & 36.021107 & 70.682961 \\
\hline D002 & 21 & $9 / 23 / 2007$ & 09:30:36 & 35.977406 & 65.193054 & 36.815323 & 65.185059 \\
\hline D003 & 21 & $9 / 23 / 2007$ & $09: 42: 51$ & 36.820065 & 65.332977 & 35.968117 & 65.330963 \\
\hline D004 & 24 & $9 / 28 / 2007$ & $07: 22: 23$ & 36.967743 & 65.807266 & 35.977993 & 65.816483 \\
\hline D005 & 24 & $9 / 28 / 2007$ & $07: 34: 31$ & 35.946457 & 65.664787 & 36.835049 & 65.659393 \\
\hline D006 & 24 & $9 / 28 / 2007$ & $07: 46: 16$ & 36.867546 & 65.506889 & 35.974480 & 65.499924 \\
\hline D007 & 23 & $9 / 25 / 2007$ & 09:47:15 & 35.972801 & 65.971336 & 36.967579 & 65.970078 \\
\hline D008 & 23 & $9 / 25 / 2007$ & 09:34:07 & 36.960533 & 66.141663 & 35.969398 & 66.139458 \\
\hline D009 & 23 & $9 / 25 / 2007$ & 09:20:37 & 35.974640 & 66.310165 & 36.973076 & 66.307739 \\
\hline D010 & 23 & $9 / 25 / 2007$ & 09:07:16 & 37.043182 & 66.483215 & 35.968658 & 66.476555 \\
\hline D011 & 23 & $9 / 25 / 2007$ & 08:54:18 & 35.969063 & 66.647987 & 36.986427 & 66.645226 \\
\hline D012 & 23 & $9 / 25 / 2007$ & 08:40:37 & 37.048958 & 66.818008 & 35.968498 & 66.812653 \\
\hline D013 & 23 & $9 / 25 / 2007$ & 08:27:39 & 35.973248 & 66.978271 & 36.923237 & 66.976875 \\
\hline D014 & 23 & $9 / 25 / 2007$ & 08:14:58 & 36.909061 & 67.149742 & 35.968372 & 67.144745 \\
\hline D015 & 23 & $9 / 25 / 2007$ & 08:02:44 & 35.973225 & 67.299774 & 36.764202 & 67.299339 \\
\hline D016 & 23 & $9 / 25 / 2007$ & 07:51:35 & 36.750862 & 67.461784 & 35.966202 & 67.455009 \\
\hline D017 & 23 & $9 / 25 / 2007$ & $07: 40: 32$ & 35.973892 & 67.613243 & 36.651867 & 67.613396 \\
\hline D018 & 23 & $9 / 25 / 2007$ & 07:30:42 & 36.550720 & 67.772514 & 35.965866 & 67.770714 \\
\hline D019 & 23 & $9 / 25 / 2007$ & 07:21:28 & 35.970299 & 67.922676 & 36.515816 & 67.923050 \\
\hline D020 & 23 & $9 / 25 / 2007$ & $07: 12: 27$ & 36.506676 & 68.083397 & 35.968170 & 68.082367 \\
\hline
\end{tabular}




\begin{tabular}{|c|c|c|c|c|c|c|c|}
\hline D021 & 23 & $9 / 25 / 2007$ & 07:02:54 & 35.967892 & 68.241600 & 36.546268 & 68.241829 \\
\hline D022 & 23 & $9 / 25 / 2007$ & $06: 52: 53$ & 36.604259 & 68.392700 & 35.969311 & 68.391945 \\
\hline D023 & 23 & $9 / 25 / 2007$ & $06: 41: 56$ & 35.981960 & 68.553070 & 36.670059 & 68.555145 \\
\hline D027 & 20 & $9 / 22 / 2007$ & 10:13:54 & 36.970470 & 68.704750 & 35.977234 & 68.702103 \\
\hline D028 & 20 & $9 / 22 / 2007$ & 10:02:06 & 35.958233 & 68.853256 & 36.903435 & 68.850182 \\
\hline D029 & 20 & $9 / 22 / 2007$ & 09:49:32 & 36.969379 & 68.997147 & 35.975246 & 68.992973 \\
\hline D030 & 20 & $9 / 22 / 2007$ & 09:37:53 & 35.952370 & 69.142433 & 36.880688 & 69.138664 \\
\hline D031 & 20 & $9 / 22 / 2007$ & $09: 25: 53$ & 36.880169 & 69.275665 & 35.981827 & 69.273872 \\
\hline D032 & 20 & $9 / 22 / 2007$ & 09:14:44 & 35.956081 & 69.407875 & 36.785957 & 69.406990 \\
\hline D033 & 20 & $9 / 22 / 2007$ & 09:02:44 & 36.919914 & 69.529114 & 35.978775 & 69.525833 \\
\hline D034 & 20 & $9 / 22 / 2007$ & 08:49:27 & 35.952564 & 69.656891 & 36.817230 & 69.653267 \\
\hline D035 & 20 & $9 / 22 / 2007$ & 08:36:44 & 36.974911 & 69.756500 & 35.983692 & 69.765945 \\
\hline D036 & 20 & $9 / 22 / 2007$ & 08:23:46 & 35.943027 & 69.882103 & 37.035347 & 69.878685 \\
\hline D037 & 20 & $9 / 22 / 2007$ & 08:08:58 & 37.178722 & 69.995522 & 35.979954 & 69.989891 \\
\hline D038 & 20 & $9 / 22 / 2007$ & 07:53:30 & 35.948544 & 70.109009 & 37.093430 & 70.106003 \\
\hline D039 & 20 & $9 / 22 / 2007$ & $07: 37: 29$ & 37.179737 & 70.221771 & 35.982929 & 70.214981 \\
\hline D040 & 20 & $9 / 22 / 2007$ & 07:21:13 & 35.963593 & 70.330765 & 37.127232 & 70.323830 \\
\hline D041 & 14 & $9 / 12 / 2007$ & 06:28:00 & 35.962093 & 70.430099 & 37.181450 & 70.430077 \\
\hline D042 & 14 & $9 / 12 / 2007$ & $06: 11: 23$ & 37.245518 & 70.530106 & 35.965771 & 70.534668 \\
\hline D043 & 14 & $9 / 12 / 2007$ & 05:54:08 & 35.969578 & 70.640472 & 37.330532 & 70.643089 \\
\hline D044 & 14 & $9 / 12 / 2007$ & 05:36:43 & 37.458996 & 70.742424 & 36.191723 & 70.747002 \\
\hline D045 & 14 & $9 / 12 / 2007$ & 05:19:54 & 36.358044 & 70.860443 & 37.661324 & 70.861107 \\
\hline K000 & 26 & $9 / 30 / 2007$ & $06: 20: 50$ & 32.133125 & 64.549873 & 34.286678 & 62.154282 \\
\hline K001 & 2 & 8/24/2007 & 08:05:59 & 32.677864 & 67.609924 & 31.501389 & 65.843285 \\
\hline K002 & 8 & $9 / 6 / 2007$ & $05: 42: 54$ & 32.449684 & 67.612701 & 33.768139 & 67.850327 \\
\hline K011 & 2 & $8 / 24 / 2007$ & 08:28:54 & 31.467379 & 65.913788 & 32.497540 & 64.004822 \\
\hline K012 & 13 & $9 / 11 / 2007$ & 04:12:00 & 33.546810 & 67.624992 & 34.561146 & 69.211227 \\
\hline K013 & 4 & $8 / 30 / 2007$ & 07:23:20 & 32.647472 & 67.539955 & 33.504414 & 69.428040 \\
\hline K015 & 13 & $9 / 11 / 2007$ & 04:41:48 & 34.533806 & 69.098289 & 34.950806 & 70.781662 \\
\hline K016 & 21 & $9 / 23 / 2007$ & 07:11:56 & 34.526077 & 69.313324 & 35.338249 & 67.311401 \\
\hline K017 & 21 & $9 / 23 / 2007$ & 07:38:06 & 35.256653 & 67.514626 & 36.068298 & 65.512756 \\
\hline T001 & 24 & $9 / 28 / 2007$ & $07: 08: 23$ & 36.158886 & 67.071342 & 36.943649 & 65.990005 \\
\hline T002 & 24 & $9 / 28 / 2007$ & 08:03:57 & 35.689156 & 65.244049 & 34.133327 & 63.359787 \\
\hline
\end{tabular}

${ }^{1}$ Coordinated Universal Time, for Afghanistan local time add 4.5 hours 


\section{Digital Files}

A high-resolution image of figure 2 and GIS vector files of the flight lines are available at http://pubs.usgs.gov/of/2008/1235/downloads.

\section{Acknowledgments}

The authors are grateful to the NASA WB-57 team for their dedication and resourcefulness in completing the HyMap data collection in Afghanistan. Dr. Terry Cocks and HyVista corporation spent long hours and endured many barely intelligible phone conversations to keep the HyMap sensor working during the long mission and difficult circumstances. Our sincere appreciation goes to the personnel at Kandahar and Bagram Air Fields in Afghanistan.

\section{References Cited}

Ashan, S., Hussain, S., Kohistany, A.H., Shenwary, G.S., Mutty, A.S., Daud, M.A., Abraham, J.D., Anderson, E.D., Drenth, B.J., Finn, C.A., Kucks, R.P., Lindsay, C.R., Phillips, J.D., Sweeney, R.E., Brozena, J.A., Ball, D.C., Childers, V.A., Gardner, J.M., Jarvis, J.L., and Liang, R.T., 2007, Aeromagnetic Survey in Afghanistan: A Website for Distribution of Data. By Afghanistan Geological Survey (Kabul, Afghanistan): U.S. Geological Survey Open-File Report 2007-1247.

Ashan, S., Hussain, S., Kohistany, A. H., Shenwary, G. S., Mutty, A. S., Daud, M. A., Abraham, J.D., Anderson, E.D., Drenth, B.J., Finn, C.A., Kucks, R.P., Lindsay, C.R., Phillips, J.D., Sweeney, R.E., Brozena, J.A., Ball, D.C., Childers, V.A., Gardner, J.M., Jarvis, J.L., and Liang, R.T., 2008, Airborne Gravity Survey and Ground Gravity in Afghanistan: A Website for Distribution of Data: U.S. Geological Survey Open-File Report 2008-1089.

Clark, R. N., G. A. Swayze, K. E. Livo, R. F. Kokaly, S. J. Sutley, J. B. Dalton, R. R. McDougal, and C. A. Gent, 2003, Imaging spectroscopy - Earth and planetary remote sensing with the USGS Tetracorder and expert systems: J. Geophys. Res., 108(E12), 5131, doi:10.1029/2002JE001847, pages 5-1 to 5-44.

Cocks T., R. Jenssen, A. Stewart, I. Wilson, and T. Shields, 1998, The HyMap Airborne Hyperspectral Sensor: The System, Calibration and Performance., in Schaepman, M., Schlapfer, and D., and Itten, K.I., eds., Proceedings of the 1st EARSeL Workshop on Imaging Spectroscopy, 6-8 October 1998, Zurich, EARSeL, Paris, p. 37-43.

ITT, 2007, ENVI 4.4/ IDL Version 6.4 User's Guide: ITT Visual Information Solutions, Boulder, Colorado.

Kokaly, R. F., Despain, D. G., Clark, R. N., \& Livo, K. E., 2003, Mapping vegetation in Yellowstone National Park using spectral feature analysis of AVIRIS data: Remote Sensing of Environment, 84, 437-456. 